UCRLJC-103816 Rev. 1

PREPRINT

$$
\operatorname{mit}_{i} I_{1} \lg _{g t}
$$

\title{
HYLIFE-II Inertial Confinement Fusion Reactor Design
}

\author{
Ralph W. Moir
}

This paper was being prepared for the proceedings of the ANS Ninth Topical Meeling on the

Technology of Fasion Energy to be published in Fusion Technology

Oak Brook, Mlineis

October 7-11, 1990

December 14, 1990

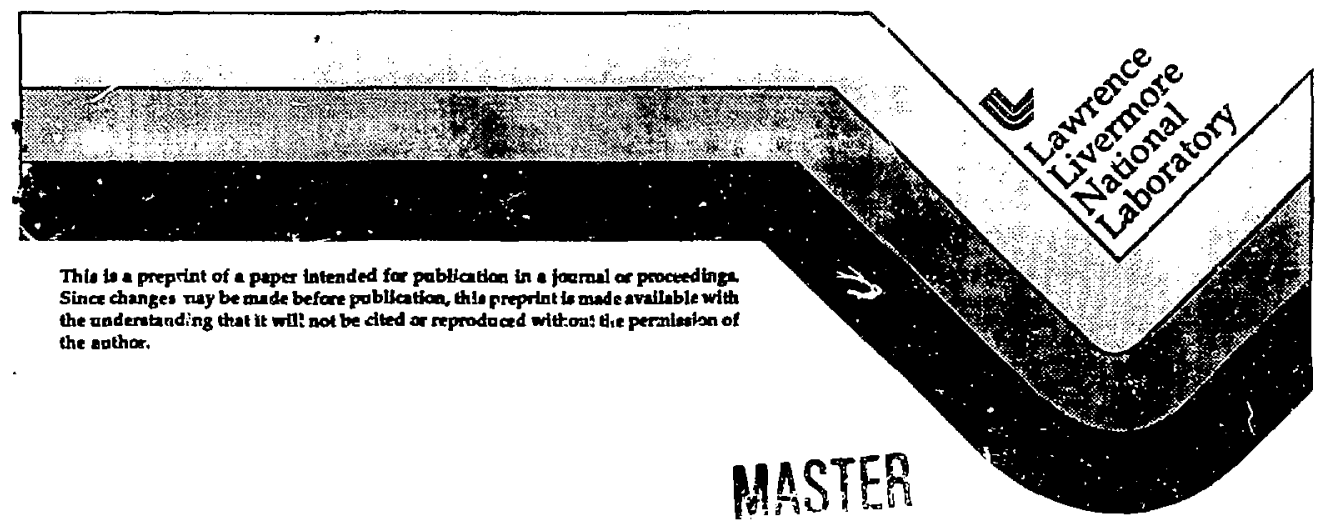




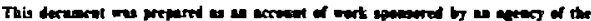

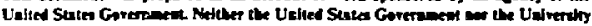

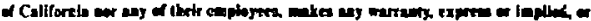

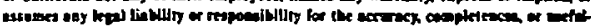

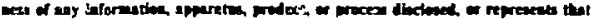

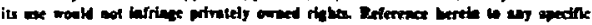

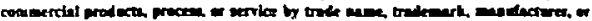

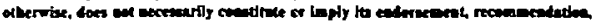

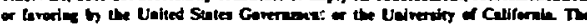

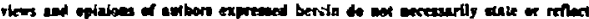

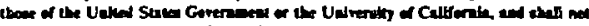

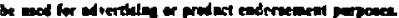


KYLIFE-II Inertial Confinement Fusion Reactor Design

\author{
Ralph W. Moir \\ Univerity of Caltorala \\ Lawrence Livermore Natlonal Laboratory \\ P. O. Bax 8C. \\ Uvermare, Calidomia 94550
}

\section{Abstract}

The HYuFE-Il inertinl fusion powet plant design study uses a tiquid tall, in the form of jats to protect the first structural wall from neutoon damage, $x$ rayn, end blast to provide a 30-y lifetime. HMUFE f used liquid lithlum HYUFE II avoids the fire haxard of lithium by using a molten salt composed of flucrinc, lithium, and beryllum $\left(\mathrm{U}_{2} \mathrm{BeF}_{4}\right)$ called Fibe Access for heavy-ion beams is pruvided. Calculations for assurmed heavy-ion beam performance show a nominal gein of 70 at $5 \mathrm{M}$ ) producing $350 \mathrm{M}$ ), about 5.2 times less yield than the $1.8 \mathrm{C}$ ] from a driver energy of $45 \mathrm{M}$ ) with gain of 40] for HYLFEd. The nominal I GWe of power an te maintained by inceesing the repetition rate by a factor of about 5.2, from 3.5 to $8 \mathrm{~Hz}$. A higher repetition rate requires faster reestablishment of the jets after a shot, which on be accomplished in part by decreasing the jet foll height and increasing the jet flow velocity. Multiple chambers may be required. In addition although not considered for HMUFE-I. there is undoubtedty liquid splash that mast be forcibly clesed because gravity is too slow. opecially at high repetition rates. Splash removal ean be scomplished by either pulsed of oscillating ien flows. The cost of electricity is stimsted to be $0.09 \mathrm{~s} / \mathrm{kW} \cdot \mathrm{h}$ in constant 1988 dollans, aboul twice that of future casl and light water reactor nuchar power. The driver beam cost is about one-half the wial cost.

\section{Introduction}

The HYLiFE-1 design (Blink et al, 1985) in which . molien salt composed of fluonine, lithium, and beryllium (Flibe) is substituted for liquid littium is called HrufE-I (Mair et al 1990 ). If will work with minor modifications of the HMLIFE- design (e.g., beam access) if urgets fouthg a yield of $1.8 \mathrm{GJ}(\mathbf{g e t i n}$ of 400 with 4 45-MJ driver) con be obtained, as assumed in HYLIFE. Splash dearing, however, was never satisfactorily scomplished in HYUFE-t. High galn $(\mathbf{1 0 0}$ results from advanced turgets and is beyond the seare-of-tine an Conventional argets are predicted wh have gairs of 70 it $5 \mathrm{M}$ ) with projected beam parameters giving a yiedd of only $350 \mathrm{M}$ !. Such low yields $(350 \mathrm{M})$ nether thar $2000 \mathrm{MJ}$ ) push us: design to high repetition tates to obtain either the same power or higher driver energy and result in rajor departures from the HYLSEF design. Because, for any tarzet desith, the gain increases with driver energy, a larger yield an be obtained with higher driver energu, but drivens are expensive and the cost incercases as the driver energy increases. The cost $\alpha$ electricity is expected to decrease as the repetition tate increases and ever: hually to rise again when pumping power becomas large. We find this rise is above $10 \mathrm{~Hz}$. We bolked at three ways to oblain a higher repetition rabe: use three chambers, pulse the fow, and use oscllating norzdex

\section{Flibe Compared to Liquid Lthium}

The fithiuin fire ha and in HMLIFE-1 wll be eliminated

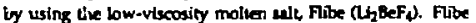
can operate compatibly with Hestelloy $N$ or 316-atairless sted at a much higher tconpersture than litifium (923 K va $770 \mathrm{~K}$ ). The heat-transfer properties, while differenc, ahould remove heat and sorve the puppose of a liquid prowating the permonent itructure from nevtron dumge and blest. Because it b not o single element like lithlum, diseadiation may slow condensation and limit the repetition ratte There is also a potential corrosion problem from furor ne compounds formed during the evaporation process.

\section{Plan: Parameters}

The pian parameters for the besc case usires pulsed flow (Hottmen, 1991) are shown in Table 1 . The power balance disgram is Fig. 1. Fystem studies are underwny to vary the driver energy, thus changing the repetition rats. The diver cost should drop as repetition rite increases, if the galn does nol drop too fast with the increasing repetition rate We have shown the cost of electricity falls rapidly $4 s$ the repetition rate increases from $1.5 \mathrm{~Hz}$ to about $\$ \mathrm{~Hz}$. There is some further cost decrease as the repetition rate increases from $4 \mathrm{~Hz}$ up to our

Txble 1. Mant Puaneten

\begin{tabular}{|c|c|}
\hline $\begin{array}{l}\text { Driver energy } \\
\text { Target gatn } \\
\text { Yield } \\
\text { Blanket multipliestion } \\
\text { Repeition rate } \\
\text { fitsion power } \\
\text { Thermil powg } \\
\text { Recirculating power } \\
\text { Pumping powe } \\
\text { Beam eiectriel power } \\
\text { Aumliary powe } \\
\text { Net electrical power }\end{array}$ & $\begin{array}{l}5 \mathrm{MT} \\
70 \\
350 \mathrm{MA} \\
1.15 \\
02 \mathrm{NW} \\
2335 \mathrm{WW} \\
3312 \mathrm{NW} \\
282 \mathrm{MWe} \\
37 \mathrm{MWe} \\
200 \mathrm{MWe} \\
12 \mathrm{MWe} \\
1030 \mathrm{MWe}\end{array}$ \\
\hline
\end{tabular}

design point of $8 \mathrm{~Hz}$. The $8 \mathrm{~Hz}$ repetition rate was chosen somewhat arbitrarily and future anaiysis on condersation, chemical recombination, splash clearing, and many other 


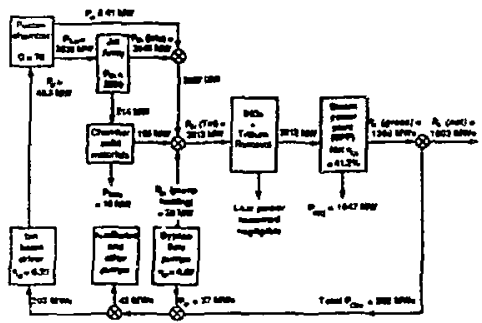

Fig. 1. Detalled power balance for the base cace HrufE-IL.

lechrical features might change the repedtion rate. A key concern is the Flibe flow rate (Table 2). The Sibe flow rate needed to reestablish the liquid wall is much langer thun that reeded to remove heal. We have reduced the fow rate from the $96 \mathrm{~m}^{3} / 3$ of HMIFE- $1066 \mathrm{~m}^{3} / \mathrm{s}$ and the liquid inventory from $1600 \mathrm{~m}^{3}$ to $750 \mathrm{~m}^{3}$. However, the dersity of fibe is four times that of lithium and we should try for furthes reductions. By decreasing the radius to the first wall from $0.5 \mathrm{~m}$ to $0.3 \mathrm{~m}$ and decreasing the flow speed, the flow rates and inventaries might be further redured, thereby lowering the coots.

Table 2 Jet Array and Primary Loop Parameter.

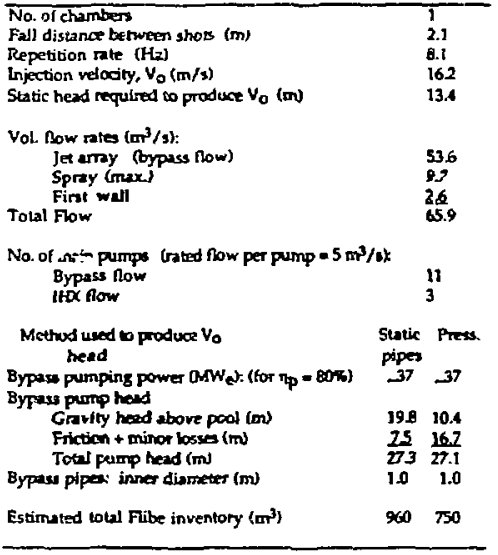

Target

The urget is designed tor heavy loro such as $20 \mathrm{H}_{\mathrm{g}}{ }^{+}$at $10 \mathrm{CeV}$. The gain depends on energy delivered to the urget, boan radius $(2 \mathrm{~mm})$, and lon ronge $\left(0.1 \mathrm{~g} / \mathrm{cm}^{2}\right)$. Target gain curves for a zerodegre beam hulf angle are shown in fig. 2. (Bangerter, 1988). We assume 30s of the enetsy, $5 \mathrm{M}$ ) for example, is delivered on a long foor" pulse of about $30 \mathrm{na}$ ind $20 \%$ is delivered in the main pulse lasting about 8 ns. If the beam half angle is $\pm 10^{\circ}$ then the gain is redued by $16 \%$ (Fig, 2b) (Moir et al., 1990). To obuin a yeld of $350 \mathrm{M}$ ) will tequire aboul $6 \mathrm{M}$ ) inpul energy (wa an ic workod out from Fig. 2 lor a range of $0.1 \mathrm{mg} / \mathrm{Gr} \mathrm{r}^{2}$ and $2 \mathrm{~mm}$ focal spot size). The correction for berm angles leading to the $6 \mathrm{MI} / \mathrm{drive}$ were not incerporated in the rest of this wort. The design work did not sonsider the target lactory, arget injection, and racking.

\section{Driver Interface Issues}

The driver is assumed to be a heavy-ion bear, although we siso considered leser and compact-10tus driver. Beause energy in a single beam is limiked, 12 separte beams are assumed to provide the rominal 5 MI wul energy. These an be directed from two sides of the reactor or from only ane side. The difficulty is o get a closepacked array with enough shielding. The beams are thown in Fig. 3. A heivy-ion driver af $5 \mathrm{M}$ ), based on $200 \mathrm{Hg}^{+}$at $10 \mathrm{CeV}$, costs in the ange of $\$ 1 \mathrm{~B}$ to
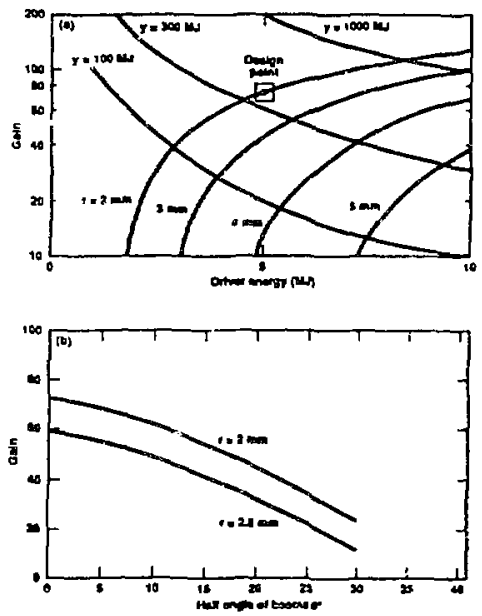

Fig- 2 Target galn on driver energy and bean half-angle. The beane upof slee ir and nage $R$ are given is parenter. The design point is $5 \mathrm{MJ}, \mathrm{za}$ in 70 , range $Q 1 \mathrm{y} / \mathrm{cm}^{2}$, and spot radlus 2 rum. The bearn angle of about $\pm 10^{\circ}$ has yet to be put into the aralyets. 


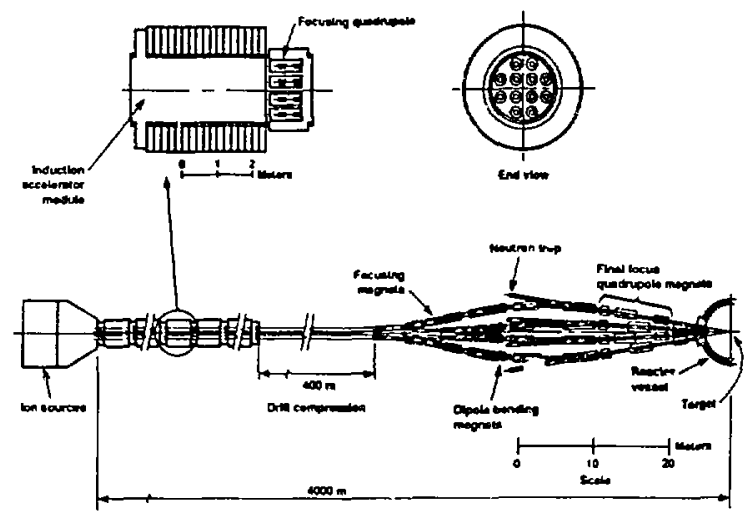

Fig. 3. As an example we show a one-sided configuration of HMUFE-fl with 12 beams using heavy. induction lines aceelerators. The length is approxitnately $4 \mathrm{~kg}$ for charge +3 or three tim. longer for Charge +1 . The find bearn fousing cognets (last 50 an) ure in a very prelianina design suge. The half-angle etrompassing all bears is $\$ 10^{\circ}$ for this artay.

52 B $\left(10^{5} \$ 1\right.$, a factor of 3 or more too high for good economics Other dnvers, such as a recirculating induction aceeterator with fewer components are possible. Another possibility is the murronion, which has as a goal to shorten the heavytion beam lines by oblaining an crder of magrinude high : . crage gradient than is possible with induction acceterators $1000 \mathrm{~m}$ long vs $4000 \mathrm{~m}$ ). Compuct tori that are acrekerted and focu sed require a much different uget and transport system design and are interesting betause of their nrder-of-mugnirude lower cost (about $\$ 100 \mathrm{M}$ ). However, they are apeculative because the expenmental parameters of compact loras acceteralons are orders of mar,ainude sway from that needed. Lases drivers have been ' artadered bul are not leading andidate at this time because of high cost low efficiency, and poor taget performance as well as the need to illurinute of the target from many angles. Our back-up stratzoy to cul the driver." contribution to the cost of electricity is lo either have one driver switched to up to fous reactors, each of $1-C W$ e size, as done in the HIBALL-ll study (Badger, J9a) or to increase the power out of the reacer chumber up lo 4 GWe. The cost and complication of switehing is probubly eccefuble when the total power is as high as 4 CWe, bat b not acreptable at 1 CWe.

\section{Chamber Mechanical Design}

A liquid fall is used to proted the find structural wall from ncutron and blast damage. The liquid breaks up es a result of sudden neutron hesting and the wrall musl be strong mough $v$ contain the Ilyire liquid ( $\mathrm{Chen}$ and Schrock, 19911; and Chen and Schrock, 19916).

\section{Stendy Flow with Maltide Ohambers}

The HYUFAt chember shawn in Fig 4 is a stesdy-now chamber. The structural wall is protected by weir Row. This requires slow flow $(10 \mathrm{~m} / \mathrm{s}$ ) and a long fall distance (about $5 \mathrm{~m}$ ) to protezt the nozzle parts from neutron darage by the curvalure of the flow over the werr. The repctition rate is low (1.5 H2) because of the long reformution time of the iot array. Splash is oniy partially cleared by gravity. The large distance above the urget lover $8 \mathrm{~m}$ ) would not be deared.

To obtain enough powe in $\mathrm{MM} / \mathrm{Fe}$ th, we consadened using up to three 27.Ha chambers (1/3 CWe each). This system would have the complicasion of swixhing beams, high pumping power, high cost for a I-CWe powet plant, and sbll not be deared of iplash. The threechumber design option was so undesirable it was droped from turther consuderation.

\section{Pulseriflow}

The pulsed how case shown in Fig. 5 uses continusous now everymtere exept for a slug of liquid $93 \mathrm{~m}$ in radius and about $1 \mathrm{~m}$ lorge injerted ot 12 to $16 \mathrm{~m} / \mathrm{s}$ for 6 to $8 \mathrm{~Hz}$ The high tepettion tate is achieved by a short foll distance of only $2 \mathrm{~m}$. A pulsed pump wo inject the slog mods ob be designed and developed to withsiand cyelic tatgue. The slug will dear splash from the beam path tras the carget It is vital thel the tralling edge of the liquid slug be sherply avt off and not leave too many splash droplets in the beom puth. Other pubed kets may be nerded te dens splasi. from the rest of the hesen palh One tsoue that requitres solution is the tsactorks neutron basting of the top of one sug that reduces its velodly and diminishes the volume for the next shot (thereby possibiy limiting the repetition rate to $\mathrm{H}(\mathrm{s})$. The downward mornentum of the liquid sang is large compared to the upward impulse produard by the micromplosion. Many issues need furthet thought.

\section{Osdllating Flow}

Another way to achicve a high repetition rate and shor fall distance with xplash closing is to osallate the $\mathrm{kt}$ nozzes horizonally, as stown in Fig. 6 (Petzold, 1991). A 


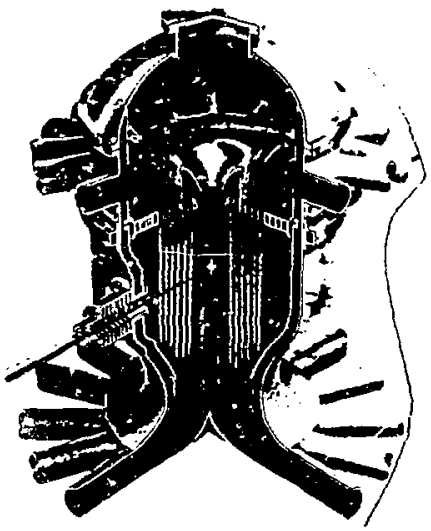

Fit. C. MUIFE-I used steady now.

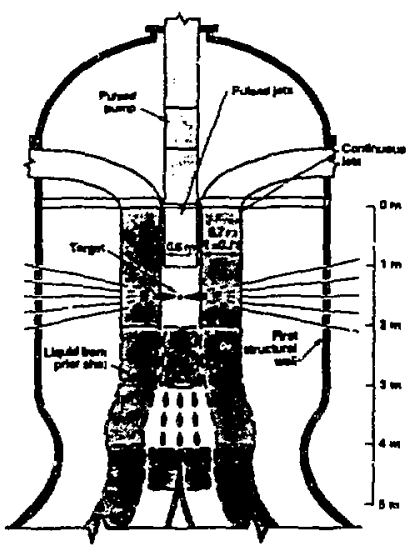

Fig 5. IMIFE-ll, pulsed now. The flow apeed for $8 \mathrm{HA}$ Ls 16 or/ with a 2-on fall height, giving a flow rate of $34 \mathrm{mb} / \mathrm{s}$.

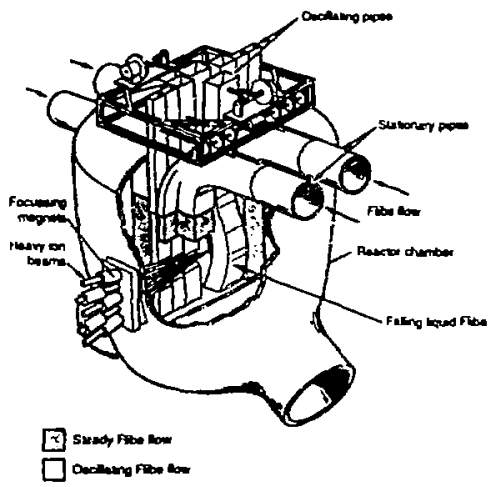

Fig 6. HYJFE-11, oscllating flow.

pocket is forred in the flow where a turget is injected and the microenplosion cocurs. The oscilating fow aweeps splash liquid from the target regior. The beam path an be deared with more osciluting flows or with prised nows of liguid. It will be necesury wo design mechurieal moving paro, heluding bellows, to allow nozzlet to oscillate at up to B $\mathrm{Hz}$ through motion of up to $\mathbf{2 0 . 1} \mathrm{m}$. Fatigue and vibration will be design probletrs. We have nox yet chosen between ascillating how and pulsed flow for our relerence design

\section{Iet Deiles Clemingend Condensution}

Steady horizoned and vettical, neutonically thick. liquid fes shown in Fig. 7 will clear the beain path and protect the heam port from radintion derrage. For gravity dening of the beam pathe, the spacing betwern these ints should be less than $S\left(S=0.5 t^{2}\right)$, where $S$ is the disurnce tiquid droplets or uplush on fall by gravity between hoth. For $8 \mathrm{~Hz}, 5=7.5 \mathrm{~cm}$ If spiesh starte with in upward relocity, the distance $S$ must be cut by up $\infty$ is factor of two. With ehis art tem splesin is not deared from all regions of the beam palh and further work is needed.

The entry from the $350 \mathrm{MJ}$ microexlosion witl emperets about 8 s ky of liquld fribe. The density of the vapor cloud when it has filled the chamber is aboun $1018 / \mathrm{cm}$.

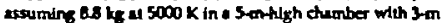
rodius. By the ume of the nexa hen $(0.175$ s for $8 \mathrm{~Hz}$ ) the dersity musi drop from $10^{11} / \mathrm{cm}^{1}$ lo ebout 3 = $10^{13} / \mathrm{om}^{2}$ in 0.125 . for propegation of heavy lons, a lactor of $3 x$ 10. Thb density reduction can come sbout by condemetion of the vapm on the Hquid fats and on the droplest lest trom the explosion (Bat and Scturock, 1991). One strategy ts to thject "cool" Flibe at $873 \mathrm{X}$ in a spracy of dropiess tn the vodrity of the beam paths.

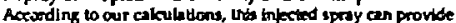
enough condensition arta without depending on the explosion ilself malding enough amul droplets of the Squid in the chamber. Our prewent madel indicates the tempet a ture in the doud drops quetely (<< $1 \mathrm{~ms})$ to s000 K. Below $5000 \mathrm{~K}$ 


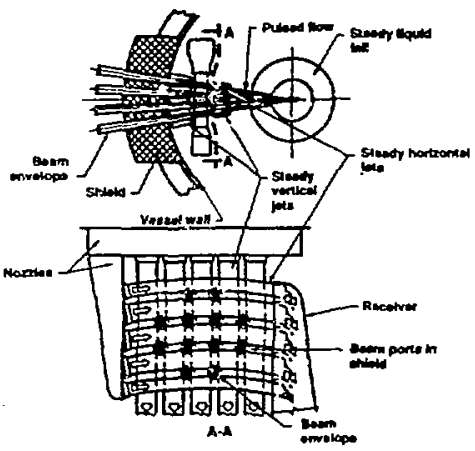

Fig. 7. Thick horizontal and vertlcal liquid jets protect the beam ports froti radiatlon and help clear splash liquid for the next shot racation is slow and conduction and convection bring the tempercture to about $1500 \times$ when the bquid surface and cloud temperature are equal, after about $1 \mathrm{~ms}$. Afre this time. condensation proceeds at the rate heat can be tansported from the liquid surfare into the cool liquid interior. Although we predict cond onsation will be 1251 enough to llow an $8-\mathrm{Hz}$ repetition rate, we recommend a definibive expenment on condensation with flibe because of the complication of condensation of Flibe dissocition products, etc

\section{Neutronics}

Neutronic atalyses of the HMUFE-ll reactor concept (Tobin. 1991) ineludes calculating the tritium breeding ratio (TBR), the system enery multoplicsion factor (SEMF). the energy deposition in the flibe and first structural wall (FSW). and the radiation damage rates for displarements per atom (dpa) and hetium production The TBR is $1.17,1.02$ of which is bred in the Fibe fall and 0.15 is bred in the reflector behind the FSW. Nearty $15 \%$ of the tritium is bred in ' $L$. The SEMF is 1.15, bringing the $2835 \mathrm{MW}$ of fusion power to $3260 \mathrm{MW}$.

Three candidate wall materials wen consklered for the FSW, two Hestelloys and a modified 316-stuintese theel where ranganese is substifuted for nided. There to a problem with corrosion of manganese so this option probubly will be drepped in tavor of urmodified 316-atalnleta steet. Results ahow that the 316-atainieal sted is a euperior choice for

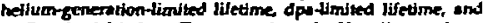
thellow buris index The areas where the Hastalloy itecls ere superior indude decty thermal power, corrotion restance. and high-temperature serength. However, the mogritude is insuficient to ouse the sted to mele The main afety tssue for HMUFE-ll are the Large shallow burlal index (106) and the requirement to contuin 99.9965 of the ${ }^{W} \mathrm{~F}$ in ventory to prevent its relesse to the public. Although fuorine is very dhervically active, in the form of flibe it is wel] tied up and not volatile Therefore spacial nuclear certification as in the ASWE (socalind N-stamp) is not neested.

\section{Tritium Systems}

Prectically all of the tritium gas emilied by exploding uargets will be removed by the vacuum pumping system but almost none of the tritium bred in the Fibe will diffuse out of the Flibe dreplets (Longhurst, 1991). At a fusion powts of 2B35 MWth with a breding ratio of 1.17 , the tritium production rate in the Flibe is $1.16 \times 10^{31}$ atoms $/ \mathrm{s}$. The corresponding radiactivity production rate is $18 \mathrm{MCi} / \mathrm{d}$, of which most will be recyded in new targets. The fraction of tritium retnoved from Flibe by the primary locp vacuum disengager (wherein a tine speny of Flibe droplets permis vitium to diffuse out and be pumped) is about $99 x$. The fraction of tritium lesking through the intermediate heat exchanger (IHX) per pass of the coolent through the IHX is $6.5 \%$, according to detailed cukculations of mass transfer during furbulent fow in the CFD. The fraction of tritiun retnowed fram the $\mathrm{NaBF}_{4}$ intermediate coolunt by the gas exchunger is greater then 99\%. Because asu on bitium behovior in $\mathrm{NaBF}_{4}$ are lacking the fraction of bitium !eaking from the $\mathrm{N}_{\Delta} \mathrm{BF}$, through the steam genetator tubes is consetvattvely assumed to be about 1\%. For these conditions, the tritium leak rate is held to kso then $40 \mathrm{C} / \mathrm{d}$, which satisfies the safety goal for routine releases.

The tritium removal system could be very large because the intermediste coolant flow rate is very large. The blast chamber and fibe piping should be double-walled, to prever! significan uritum leakage under normal and off-nomil conditions. Beryllium metal will be used to neutralize free nuorine tiberated in the ribe by nuclesr reations The greatest ineed for future work is to design the varuum disengager and gas exdhanger to quantify the sise, power dissipation, and cost associated with achieving 995 efficiencies.

\section{Materials and Molten Salt Technology}

\section{Comostibillby and Conrosion}

We chose a high-niekel steet for our vesel material and pipes. A 316-stainjess sted will work with adequately low corrosion rates, and nodified Hestelloy $N$ (a high-nickel steel) will wark even better. In the future we nught consider the use of arton-carbon composites for the vessel material because graphite is compabible with the molter salt it isium retention is not too serious. Pyrolytic graphile hus low retention but porous forms of graphite have highe retention. The use of - graphite vesset will reduce activation, increase tritium breeding, and reduce the hest leak to the shield.

\section{Chemlen Kinetics of Dissocinted Flibe}

We know that when Flibe is dissociated into it constituents by the mionexplosion about $9 \mathrm{~kg}$ of Fibe is raised to $5000 \mathrm{~K}$ (Recent investigations nul fointed into this work suggest this temperature may be as much a ten imes higher.) These constituents will reform Fibe and not other species. That b. Flibe is stable under radistion and the recombirstion reaction is sirong; however, bused on preliminary study, we believe that the recombination is sufficiently last not to be a limiting fector in the condensation of tlibe vapor on liquid dropiet furtaces. An issue with condensation is that the constituenb of Fibe must chemially recombine and sick on striking the droplet surface. Too low a sticking ratio will slow condensation. We think $L F$ will have a sticking coetficient of al lcast 0.5. We are concermen that the BeF muy bounce oft 
liquid surfaces many times before sticking and folning the bulk liquid (sticking coefficient may be 0.01 to 0.0 ;). If the smull sticking coefficient is not limiting we have shown all other orocesses are fast enough to permit a repetition rate as high as $8 \mathrm{~Hz}$. This is an arca for further study and a definitive experimenl is needed.

\section{Chaice of Tirect Materlal}

We chose tantalum for use in the urget beesuse it is relatively righ $Z(Z=73)$ and is soluble in Flibe. We can make coatings by chemicai vapor or liquid deposition. Many other high- $Z$ materials we could have chosen, such as lear. and tungsten, would precipitate on the walls of the vessel and pipes, making seonvery cifficult and cousing other problers

\section{Bal ance of Plant}

The power fow disgram is shown in Fig. 1 . The components emphasizing the bulanx-of-plant (BOP) (Hoftman, 1991) are shawn in Fig. 8 . We have shown the eutectic composition of Fibe thus mels at $636 \mathrm{~K}\left(363^{\circ} \mathrm{C}\right.$ ) is practical but costly because of its high viscosity therefore the lowviscosity composition tut melts at $733 \mathrm{~K}\left(460^{\circ} \mathrm{C}\right)$ was chosen. Our use of molten sali relies heavily on eariy work at ORNL on the molten sall resctor (Rosenthal et al. 1972). The intermediate coolant NaBF, was chosen (Briggs, 197) in part because of its tendency to hold up tritium in the form of $\mathrm{T} X \mathrm{O}$ and reand its passing on into the steam system and hence to the envirorument.

\section{Safety and Environment}

An oulstanding leature of the HYIFE.II reactor is its favorable safuty characteristics [Dolan and Longhurst, 1991]. Sufcty and environmental goals for HYUFE-II include.

- oftsite dose fronu severe accident less than 2 Sv $(200 \mathrm{rem})$ for passive solely.

- no N-tamp requirement for most components, requines less than $0.25 \mathrm{~Sv}(25 \mathrm{rem})$ offsite dose.

- working area dose rate less than $50 \mathrm{mSv} / \mathrm{h}(5 \mathrm{mrem} / \mathrm{h})$ for a low docuparional risk

- dose from mutine atmospheric efluents less than $50 u \mathrm{~Sv} / \mathrm{y}(5$ $\mathrm{metr} / \mathrm{y}$ ).

To evaluate the polential to mect these goats, the consequences of a severe accidort involving blast chamber

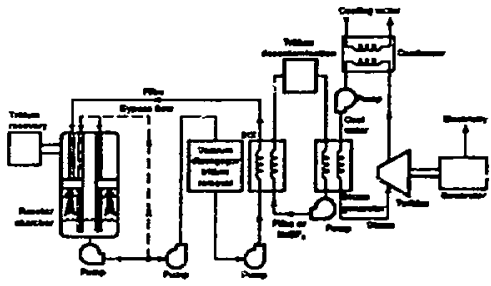

Fig. 0. The reaction chumber and powes conversion system for HYitFE-1L. fallure and bresch of containment are sludied, including the effects of activation products, tritium, and beryllium toxidity. HYLIFE-ll has no large sources of energy available to disperse radioactive mascriale. The tritium inventory in the flibe could be kept very low (about $1 \mathrm{~g}$ ). The dominant ictivation product is aboul $300 \mathrm{MCl}$ of $11 \mathrm{~F}$ (hulftife $110 \mathrm{~m}$. A vety small fruction is $\left.\times 10^{4}\right)$ of the Flibe ectivation products would be mobilleed. because the microexplostion vaporizes about $9 \mathrm{kp}$ from the $1500 \mathrm{t}$ of Flibe. Orly a fraction of the mobilized vapor would escape from a hole in the blact dumber, and only a fraction of that. from a hole in the containment building. The ${ }^{18} \mathrm{~F}$ offsite dose from a severe acsident (breaching both the blast chamber and the containment) would be less than $02 \mathrm{mSv}$ (20 mrem). Thus, N-stamp requirments can be avoid $\mathrm{d}$ in the main reactor components, and the passive safety goal can be met

If the maximum vulnerable trittum inventory in the arget factory and tritium handling system, were less than 2.5 $k 8$ then the maximum offsite dose from its relase would be les: than 0.25 Sy $(25 \mathrm{rm})$, and the $N$-alamp requirement could be avoided for those systems as well. Some contact mintenanoe should be feasible on the NaBF, secondary loop, but nol on the Flibe primary loop (unless a very effective impurity removal syatem were operating and activalzd impurities did not flate out on pipe walls). Axtivation of meallic impurites in the Flibe from a $\mathrm{N}_{2} B F_{4}$ second ary coolant leak from corrosion products, trom target materials, or from a Mof o comosion inhibitor (if used) could fesult in high dose rater. The accuputional risk govl an be met if personnel do nos work in the primary coolant loop ares. The routine effuent gal is met provided the tritium removal systems in the primiry and intermediate coolant loops are made large enough. After $30 \mathrm{y}$ of operation with a So-am-thick Fibe kt turtuin, the dose nte from the blast chamber (made of high nicket sted such as Hastelloy or suinless steel) would be too high for shullow iand burial.

\section{Economic Analysis and Systems Issues}

The Salire economica and sysiems analyzis code was uted to sludy some trends in HYIFE-2l (Bien, 1991). Some but not all of the aigorithms in Safire were changed to model the chamber and IHX using flibe instend of lithium, therefore the ritrds are anly suggeslive. A series of curves plotte! apaisst repebition rali show the important teshures (Fig. 9). As the repetition rale drops, the yield per shol goes up dramatically to minisis power. To get a higher yield, the driver energy must go up, whith odds dramatically to the total plant cose, epecially as repetition rate drops. The electrical power to the driver is protically independent of repetition rete sbeve \& few Herta for our base ase gain curve. The driver power b about 100 MWe. As the repetition sote increases the pumping powet increases, bul not enough to compensale for the falling driver cost, thus the cost of electricity b a falling function of repetition rate. The repetition rate of $1.5 \mathrm{~Hz}$ of HruFet has a cost 607 highes than at $8 \mathrm{~Hz}$ HVIJEE. I was optimized for targets that were then thought to have much higher gain.

The cost breakdown is given in Table 3 for ase with a 5-MI driver operating at a $75 \mathrm{~Hz}$ repetition rale This code resull is somcwhat differenl from the $\theta .1 \mathrm{~Hz}$ of the rest of the study. The cost of electricity is about $0.27 \mathrm{~S} / \mathrm{kW} \cdot \mathrm{h}$ for current dollars or $009 \mathrm{~s} / \mathrm{kW} \cdot \mathrm{h}$ !er noninhated constant 1988 dullars. If the driver direct cosi were to drop by a factor ef 4 , from $51300 \mathrm{M}$ to $5.525 \mathrm{M}$, the coss of electricity would drop by 405 (to 0.055 \$/kW.h), which is close to that of furure cosl and bight-watcr rcsave (LWR) nuclar power costs of 0.04 to $0.05 \mathrm{~s} / \mathrm{kW} . \mathrm{h}$. 

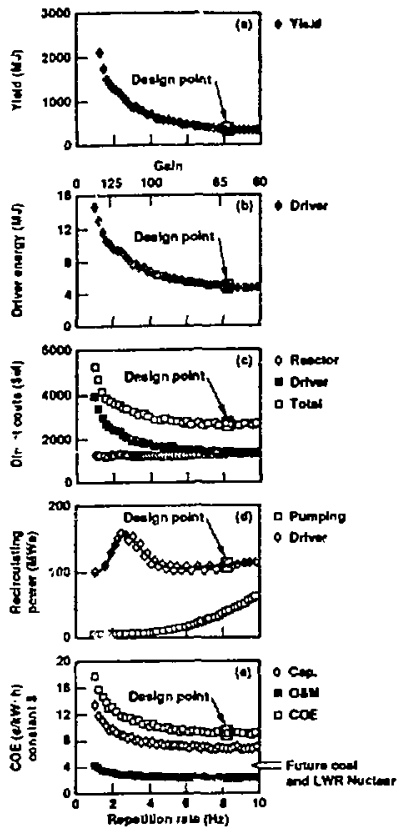

Fig 9. (a) Yicid os metition ate. (b) Detver energy vs repetition rte. The gain is given as well. (c) DLrect capital cost vs repetition rate. (d) Recirculating power ve repetition rate. The driver fower differs frow that of the rest of the paper by a factor of 2 because the injection efficiency used in Fig. 1 was $20 \%$ and about 35\% was used in Safure. (e) Cost of electriclty va repetition rate. Note that this cost is close for the desizn point of the 96 er.Weh in the paper by Hoffman icot.

\section{Summary and Conclusions}

In the design known as HMFE-ll, we have substituted Fibe for libhlum and modified the HMLFE-1 design to obtain repettion rate up to $8 \mathrm{~Hz}$. We eramined pulsed and cxilating flow concepts to obtain this high repetition rate and w remove splash liquid from the bam lines before the nert thot. Condensation is prodicted to reduce the Flibe vapor to Low enough value to penmit an B-Hz repetition rate. The fire hazard has been eliminated and safety requirements met but not stullow burial upon decomurssioning).
Table 3 Mant Cost Breatedom

\begin{tabular}{|c|c|c|c|}
\hline Acet & Item & & Cost (million 5 \\
\hline 20 & Land and land rights & & 5.0 \\
\hline 21 & Structures and improvements & & 280.2 \\
\hline 22 & Reactor plunt equipment & & 551.4 \\
\hline & Tracking align systems & 30.4 & \\
\hline & First wall systems & 1.6 & \\
\hline & Tritium extraction systems & 1.6 & \\
\hline & Blanket and shicld & 325 & \\
\hline & $\begin{array}{l}\text { Heat transport system } \\
149.5\end{array}$ & B.4.4 & \\
\hline $\mathbf{2 3}$ & Turbine plant equipmant & & 229.8 \\
\hline 24 & Electric plant equipment & & 90.9 \\
\hline 25 & Miscellaneous plent equipmen & & 595 \\
\hline 26 & Main that rejotion equipment & & 41.1 \\
\hline 27 & Drive equipmenl & & 1397.3 \\
\hline $\mathbf{2 8}$ & Target fackory equipment & & $\begin{array}{r}128.8 \\
2783.9\end{array}$ \\
\hline & Tolal direct cost & & 2783.9 \\
\hline 91 & Construction, scrvices & & 556.8 \\
\hline $\boldsymbol{q}$ & Home office enginccring and $y$ & ervices & 417.6 \\
\hline 93 & Field office engingering and se & rvices & 278.4 \\
\hline 年 & Dwncts cosi & & 194.9 \\
\hline 95 & Project contingengy & & 423.2 \\
\hline & Total overnight cost & & 4654.7 \\
\hline & & $\begin{array}{l}\text { Currents } \\
1996\end{array}$ & $\begin{array}{c}\text { Constant } 5 \\
1988\end{array}$ \\
\hline 96 & Excalation during construction & 15022 & 0.0 \\
\hline 97 & Intcsest during construction & 1955.1 & 134.8 \\
\hline & Total capilal cost & 8112.0 & 5089.5 \\
\hline & Cost of clectricity $\langle e / k W h\rangle$ & & \\
\hline & Capilal & 21.12 & 6.79 \\
\hline & Fucl & 0.03 & 0.01 \\
\hline & O\&M & 6.97 & 2.24 \\
\hline & Total & 28.11 & 9.04 \\
\hline
\end{tabular}

At present, the design and pertormance of the system depend on many asumpions that must be venticd by future anstysis and experiment before we can have a high level of confidence in the predieted perinmance. Some of the key issues include verifying splash remaval techniques, tritium remaval eflectivencss and permeation rates, condensstion phenomena and sticking coefficients, heavy-ion accelerator uchnology and cost reduction, and besm propagation. To be competitive with future call and LWR nucless power, the cost of elertriesty nesds to be reduced by a factor of 2

\section{Acknowledgements}

We thent theny people on the ICF program stoff at the Lwrence Luermore National Laboratory for advice throughaut this study. This work was pertormed undes the suspices of the U.S. Dipertment of Energy by Lownence Lvermore National Laboratory under Contract W-740S-Eng-48.

\section{References}

Bai, R. Y., and Schrock, V. E. (1991), "An Approximate Method for Analyzing Transicnt Condensation on Spray in 
HYLIFE.11, to be publishad in Proc. Ninith ANS Topical Mecting in the Tech. of Fusion Energy, Fusion Tech. May.

Badger, B. et al. (1984), HIBALL-II-An Improoed Conctotual Heary ion Beam Drioen Fusion Reactor Study. Univ of Wisconsin Repor, KJk-3840. FPA-S64, UWFOM-425.

Bangener, R. C. (1968). Targets for Hescy-lon Fus. M, "Fussion Tech., 13, 349

Bieri, R L (1991), Tarameric Studics for a HVIFE-11 Electric Power Flont,- to be publishad in Proc. Ninth ANs Topical Maeing on the Tach. If Fusion Energy. Fusion Tech, May.

Blink, J. A., Mogan, W. J., Movingh, J., Mericr, W. R. and Pirts, J. H. (1985), The High-Yield Lithixm-Injertion Fusion. Energy (HYLIFE-I) Reactor, Lawrence I vermore National Laboratory, Livermore, Culif, UCID-535s9.

Brigg, R. B. (Winter 1971-1972). Tritium in Molten-Sal Reactors," Reaclor Tech., 14, 335.

Chen, X. M, and Schrock, V. E. (1091a), -A Note on the Pressure Field Within an Outword Moving Free Annulus," to he published in Fra. Ninth aNS Topical Mecting on the Tech. of Fusion Energy, Fusion Tech, May.

Chen, X. M., and Schrock, V. E. (1991b), The Pressure Relaxation of Liquid Jes After lsochoric Heating " to be pubiished in Proc. Ninth ans Topical Meeting on the Tech of Fusion Energy. Fusion Tech. May.

Dolan, T. I., and Longhurst, G. R. (1991), Salety and Environnental Aspects of HMUFE-II," to be published in Proc. Nintli ans Topical Merting on the Texh. of Fusion Enngy, Fusion Tech., May.
Horfmen, M. A. (1991), The Heat Transport System and Tunt Deign for the HYUFE-II Fusion Reactor," to be published in Fusion Tectrnology.

Lorghury. G. R. (199)), Estimuling ' Tntium Losses Trough HYire-11 Heal Exchangers," to be published in Proc. Ninth ANS Topical Mecting on the Tech. of Fuion insogy, Fusion Terh., May.

Moir, R. W., Adamson, M. G., bangeriet, F O., Bieri, R. L. Condit, R. H., Hartman, C W., Langdon, A. B. Logan, B. G., Orh, C. D. Fotzoldt, R. W., Bits, I, H., Posi, R F., Sacks, R. A., Tobin, M. T., Dolan, T. I., Lor iurst G R. Holiman, M. A., Schrock, V. E., Bai, R. Y, then, $X$ M. LiL, I. Sire, D.X., Mcier, W. R. (1990), Mreire.ll Progias Reptit, Liwrence Livetmore Nationul Luboratc ry, Livermore. Clif., UCla-21816.

Rigizoldt, R. W. (1991), "Oxeilieting Liquid Row 'n ICF Reacton," to be published in Proc. Ninth ans Topical Meting on the Tech. of Fusion Encrgy. Fustion Tak., May.

Ronenthas, M. W., Habenreich, P. N., and Briggs, R. B. (1972), The Derelopment Status of Mollem-Solf Breder Ructore, Oak Ridge Nationsl Luboratory. Ouk Ridge, Tenn, ORNR 4912 .

Tobin, M. T. (1991). Neutronic analysis for HYJFF-II," to be published in Proc. Ninth ans Topical Marting on the Tech. of Fusion Encrgy, Fusion Tech., May. 